University of Rhode Island

DigitalCommons@URI

Open Access Master's Theses

1959

\title{
Group Discussion as a Medium for Qualifying Concepts of Social Behavior in the Junior High School
}

Jack Randall

University of Rhode Island

Follow this and additional works at: https://digitalcommons.uri.edu/theses

\section{Recommended Citation}

Randall, Jack, "Group Discussion as a Medium for Qualifying Concepts of Social Behavior in the Junior High School" (1959). Open Access Master's Theses. Paper 1560.

https://digitalcommons.uri.edu/theses/1560

This Thesis is brought to you for free and open access by DigitalCommons@URI. It has been accepted for inclusion in Open Access Master's Theses by an authorized administrator of DigitalCommons@URI. For more information, please contact digitalcommons-group@uri.edu. 


\section{BF 199 \\ R3 36 \\ 1959 \\ C.2}

GROUR DISCUSSIOT AS A MRDIUM

FOR QUALIPYIYO CONCEPTS OF

SOCIAI BEHATIOR II THE

JUNIOR HIGE SCEOOL

BI

JAEX RAMDATL

A PHESIS SUBMITRED IX PARTIAI PULPELLMERT OP THE

REQUIRBUGHTS TOR THE DBGRER OP

MASTER OF SCIBHOE

II

BDUCATION

UNIVERSITY OF RHODE ISLAND

1959 


\section{ABSTRACT}

The objeotive of this study is to determine what influence group discusgion has on eighth grade students relative to changling their concepts and attitudes toward problemg of social behavior.

An overview of the literature, and other possible sources that were pursued, Indicated that the age of adolescence finds the youngster becoming more group centered. The thoughts and opinfons of eighth graders shared with their peers have an ffoct in molding conoepts of behavior. It was Indieated that more emotionel intolvement takes place In student-centered rather then counsezer-eentered group discussions.

In order to sample the optaitons and beliefs of elghth graders, two equivalent questionnalres of twenty-fite questions each were prepared. The questions concerned problems that are comon among junior high school youth. For each question the student was required to check one of three angwers: "Yes," "Don't Know," and "Ko." The testing wes confinca to seven group guldance clasees of eighth graders, totaling 194 students, from the Samuel Gorton Junior High Sohool, Warwiok, Rhode Island. Four of the classes oerved as experimental eections; the remaining three olasses constituted the control sections. 


\section{1}

The first questionnaire was administered to all seven group guidano elasgen. Fach question was reviewed and disousssed in the four experimental sections. With two of the experimental sectiong the digousglons were otudentoentered counselor-eentered disousions were oonduoted with the other two sections. Ho review of the questions was allowed with the three control sections. After discusgions the second questionnaire wa given to all seren group guidance olasses. A followmup was made with two of the experimental seotions during the early part of the sucoeding school term, when the pupils were in the ninth grade. The experimental section heving a higher median IQ exhibited more spontaneity in disousgions. This general reaction was observed under both student- and counsezorcontered leadership. The majority of atudenta in theae groups came from middle or upper middle clasa homes. The compariaon of anvwers which made up the total shift of group opinion indicated that, after digcussion, the experimental group in general seemed to be less certain in thelr choice of angwers and more refleotive.

Resulta of the study revealed that the response of experimental seotions, after disoussion when oompared with those of the control groupa, showed Ilttle change in the conceptg of beharior attitudes. The study attempted to modify attitudes and concepts many of which had been formed prior to the youngster's entering junior high school. It may be appreoiated these att1tudes, like hablts, are not easily changed, and disoussions over a period of time may be 
$1 \nabla$

required in order to effect any modification of the pattern of the respondent's thinking. It appears more positive results can be expected if opinions and concepto have not become fixed before group discusgions are held. 
TABLE OF CONTENTS

Page

IIST OF TABLES. . . . . . . . . . . . . . . vi Chapter

I. STAFBLCEN OF PROBLEM. . . . . . . . . . 1

II. SURVEY OF IITERATURR. . . . . . . . . . 4

III. METHODOLOGY .............. 10

IV. PRESTHTATION ON DATA. . . . ...... 14

$\nabla$ CONOJUSIONS AKD RECOMMARDATIONS . . . . . 25 AOKNOWLEDGEUENS. . . . . . . . . . . 35 APPEHDIX. . . . . . . . . . . . . 36 BIBIIJGRAPHY. . . . . . . . . . . . 42 


\section{IIST OF TABLES}

Table

Page

1. Percentages of light, Don't Know, and Wrong Responses to Two Hatching Liste of Questions by Student-Centered and counerezor-centered Bxperinental Sectione of Elghth Grade

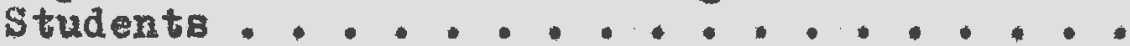

2. Pexoentages of RIght, Don't Know, and rrong Response to Two liatching Iista of questions by Control Sectione of EIghth Grade Students .......................

3. Comparison of Peroentage Change in Responses Among dxperinental Seotions Between Adminiotration of Iist $A$ and Iist B.......... 18

4. Comparison of Percentage Change in hesponses Among Control Seotions Between Adminiotration of Iist $A$ and Ilat B .........

5. Average Percentagen of Change for Combined Experimental and Control Sections......20

6. Compariaon of Hental Ab111ty of all Seven Group Guidance Seotions. . . . : . 21

7. The Pereentages of R1ght, Don't Know, and rong Rerponser made by two sighth Grade Bxperimantal sections on Two Ifots of Ten Matehing Questions selected Irom LIats A and $\$$ with Subsequent Pollow-Jp When the Puplis were in the Ninth Orade. . . ..............

8. Comparative Shift of Opinion of Two Bighth Grade Experimental Sectiong using Two Ilats of Ten Hatching Queations fron Iigta A and 1th Subsequent Follow-Up When Pup11s were In the NInth Grade ............... 


\section{CHAPTER I}

\section{STATRHEVT OF PROBLEM}

The juniox high sohool, as an institution, has come under severe oriticism in recent yearg. Group guidance in the junior hlgh sohool program has borne its share of this orit1c1am. It is the thinking of some that group guidance activities should be abolished or curtalled. It would appear that to strike out group procesa is to ignore the natural inolination of youth to talk over adjustment problems among themselver. The objective of this investigation is to ascertaln to what extent concepts of pocial behevior can be qualified through group discusgions. Whether or not to continue group guidance as atructured procedure in the junior hlgh school 18 part of the probler of this study. More spec1fieally, the investigations seek to determine tine differences in modifications of attitudes between group-oentered and counselor-centered approsches. For the purpose of implementing this study, seven groups of eighth grade studento from the Samuel Gorton Junior High Sohool, Warwiek, Rhode Island were chosen.

At the junior high school age boys and girla are becoming an integral part of the community. At this age, they may or may not be aware of having to make adjustments. 
Wany of their attitudes and conoepta of behavior are frequently not condoned by sentor members of thelr families. The adolesoents notion that they are becoming inereasingly the subject of adult disousgion.

The junior high yearg of preadolescence is a period of rapid growing up. At this time the pupils are beginning to find that group-importanoe supergedea ael1-importance. A new feeling of kinship has been awakened. There is a desire to share experiences with those of the ame age group. Soclal concepts, formed during the interval of Ilfe when they were more individualistic, need to be reviewed in the light of the new deaires for group identification.

The group has a profound effect in shaping the thoughts and actions of the adolescent. As Jersild ${ }^{1}$ ind cater, It outwelgh the influence of the adolesoent's parents or teachers in rlany areas of his 11fe. Unstructured peer group intergction, involving such feelings as idontification and belonglngness, will contribute to the modification or development of ettitudes of behavior that is not often realized in formal teacher class alscussion. When confronted with certain situations, the natural tendenoy of this age group is to share confidences with their peers which makes them anxlous to exchange views on choloes of behavior. It is the oonviction of Jersild ${ }^{2}$ that young people have more capacity to inquire into the meaning and implioations of

I Arthur $T$. Jeraild, The Psychology of Adolegoence

(The Mackillan Company, New York. 1957), p. 209

${ }^{2}$ Ibid., p. 89 
their beliefs than 1 s generally consldered to be possible in the school program. The influence of group milleu, using otructured material covering attitudes of soolal behavior, may result in some desirable modifications. 


\section{OBAFTER II}

\section{SURVIR OF ITPRRATURE}

How oogcepta of behavior are cormed. - The oarlieat experiences of the ohild are assoctated with his parents. It Ig during prefohool yeare that ooneepts of behavior which are subequentig erideneed in the sohool and nelghborhood etmogher have tholf beginning. The nolghborhood and peer gronp asootation provide an arena for exerefolng. supplenenting, or modifying theme beliefs. Coleman inaken this observation as a preliminary to his otudy of personality derelopment:

The inportano of the early years for latex personality derelopment ha, long been recognisad, as evidenced by the comen saying $A$ s the twis is bent; the tree is inolined and "The onlld is father to the nan," However, It remained for Sigmund reud and later twentieth-entury investigators to grasp the gl gnificance of the ariy formatre years for later personality adjustment. For it $1 \mathrm{~s}$ Ging tilis period that the foundations are lald for our adult onviromental and self-eraluations, hablts of think1ag. and patterns of reactions. I

Jane Farters ${ }^{2}$ olate that bohartor-1to weoc, artios,

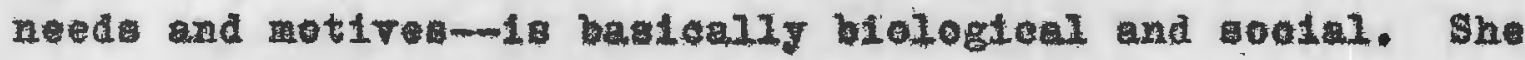
elaselfle bohavior tnto two groups! (2) the blologleal assoolated with Inditidal aurvival and continuity of the spectes,

IJanes 0. Colenan, Abnomal Porohologr and Yodern itfe

(Chleago: \$oott, Poresman and Company, 1956), p. 125

Jane Warters, Hien Sohool Personnel werk Today (Now York: MoGraw-Hill Book company, Ino.. 1956), P. BI 
and (2) these motived that are coelally learned through memberahip in a socioty. The soolally conditioned noeds derelop from the blologteal they are atngled and extended within the fanily.

Hollingohod conours with Tartere when he mentions:

...IIret, chlldren's behavior pattems are ostablished prinarily by their early exporienees in the farily and ceondarily in the nelghborheod; and, second, dillar expertenoes in fandiy and neighborhood mold ontldren in ainilar cocial typee becaupe their learning in both areas tends to be atrongly asoociated with olass. I

There 1. evidone that the adolesente have certaln opinlous of rlght and wrong which har been falrly well ostablished before crituring sohool. Hueh has been learned from parents, playnates, and others to whon they have been ometionally attached. The sehool tends to play a more or

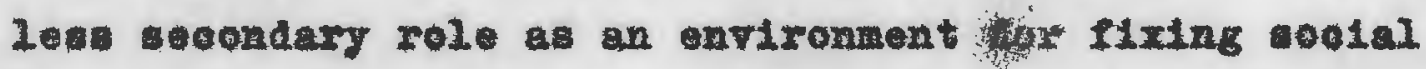
attitudes.

The olass room with 1 to fomalized methods of instruetion tende to have IIttle effect upon the preconectred patteras. of thinking regarding oholoes of bohariof. In disoueatng this polnt it is interesting to note what Harlghurst and Peba tata:

Horal bellefo are formed by accurulating reaction: to immediate altuations, not by a consclous formulation of generalieed oode of conduet. This refleots the fact that the teaching of what is right and wrong is done with referonee to 100 lated, conerete acte of bohavior, relatively 11 ttie effort is made to help young people generaltae fron these st tuatione or holp them develop a coherent moral philosophy.

1Auguat B. Hollingahead, BLutora's Xouth (Iew York: John V1let sore, Ino., 1949), p. 444

2. I. Hav1ghurgt H. Taba, Adolesecnt Charaeter and

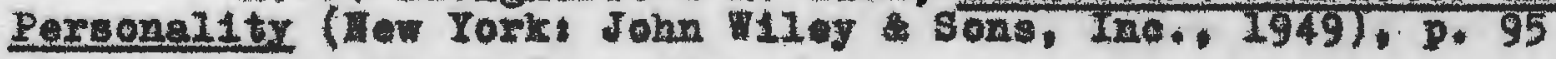


Havighurat, In collaboration 1 th Hougarten, 1 algarows the elaim that a ohild's character is molded by what ho ragds: Reoent turest1get1ong have tphold his doubt of thie influpree, This is partioularly true in a coolety wher a child has pereonal relationulps of some emotional intenaity $\mathbf{\text { Ith }}$ a rariety of people outside the inadiate fanily. Havighurst and reugarten oonelude that it is doubtful that ohild learno as much from characters in a book as he learas from the people with whom he interate. From evidenoe ofted, it appears that conoepts of beharior are not formed by a olngle dominant foroe woh as environmental, biological, or soolologioel. It geems to be the comblned effect of these three.

Modification of behavioral oonoepts through mour digcussion. - The adolescont is energing from self-eentered to a group-eentered lovel of cevelopment. The dealre to be Identified with a peer group through subseribing to their actlone, secth, mode of drese, and thinking, is dontnant with this age. Sinoe youth has a ditinet attaphent to group activity, 1 could be through the dynamices of group action that the change in any one Individual' behavioral oopeopte might be aceompliahod. Strang oupporte this point of riew:

The member's habitual way of thinking are challenged by new points of Tiew by his peers. Thus, In many ways, through partiolpation in group life, the tadent ie alded in self-discorery and aelf-realigation. 2

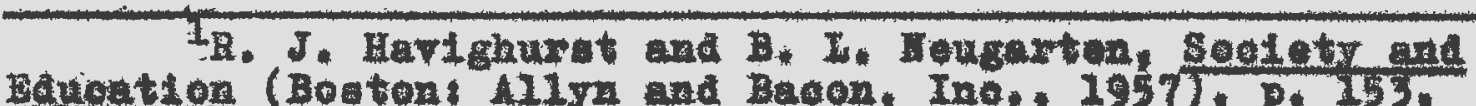
Futh Strang, Group Wort in Bdueation (Iew York: Harper and Brothers, Publishore, 1958), P. 19. 
In another part of her book, Strang points out the probable ralue of group discussion in developing sociel attitudes and convictions?

A dicouasion may also hav the pereonal value of bullding healthy mutual attitudes. It may relieve teneions, Increase goolability, and lead to deeper convictions about one's own bellefo. It may olartey certain personal probleng by obtaining the more objeotive viekpoint of others on them. 1 .

It appears that group discussion can have a profound effect on the points of view of those who partielpate. In this connection Bennett makes the following tatement:

Uniformly, the experiments established that group dicousion 1 a more effectire instrument for influencting attitudea than the leoture method.

Jones has this to asy about influencing the moral

knowledge of children:

Erldence has been presented to ghow that messurable improvement in moral behavior was affected through one of our teaching thods, namely, the experienoing plus discussion ethod. . . Over against the positive finding, however, is the sobering fact that the amount of the improvement in this experiment even under our most successful method was mall:

However, it may be sald that the results of this otudy lead us to belleve that though all instimetion in character should be indirect from the point of view of the learner, it should be dreot or planned rather than indidental or unplanned from the point of view of the teacher. 3

It is understendable that the results of experiencing plus disoussion cannot be great, owing to the brief period during the dey that the youngster is in gohool. It oan be

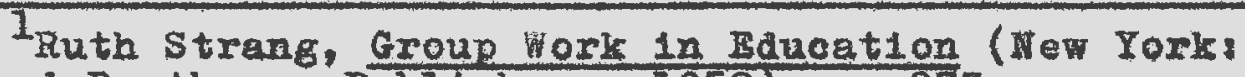
Harper and Brothers, Publighers, 1958), p. 273

$2_{\text {ifargaret }}$. Bennett, Gujdance in Groups (New York: MoGram-H111 Book Company, Inc., 1955), p. 107

${ }^{3}$ Tornon Jones, Charaoter and Citigenship Training in the Publlo Sohool (Chicago: The Unlversity of Chleago Press, 1936). $90 \cdot 180-81$ 
imputed that the instruction ahould be indireet from the point of view of the student but direot and well planned from the point of view of the group guidance oounselor.

$$
\text { The group approaoh. -Warters } 1 \text { indicates that group }
$$

guidance is deaigned to impart information needed by students and to help them soolalige their attitudes, habits, opintons and Judgments. It is to help them develop the power of self-direction. Students are often able to digcugs in a group those problems they find difficult to discuss in a private interview. It helps the shy student to overoome the feeling: of 1solation and to verbalize fears and anxietles. Guilt feolings can be alred, tensions released, and issues clarifled. According to Humphrey ${ }^{2}$ there are two types of group guidance orientation, factual and attitudinal. With the factual approach, the counselor prepares information to be studied or disoussed. With attitudinal approsoh, not only w11 acquisition of knowledge be stressed, but the students w11l be helped to develop attitudes that make for self-direetion and self-management. The soope of this study will bo confined to the results of attitudinal orlentation in qualifyling consapts of sooial behavior.

With this study, two alfferent methods of group discussions were used. In the one method, the direct or counselor-oentered, the counselor conduots the disoussions, weighs and channels the responses. The other, known as student-

IJane Warters, High Sohool Personnel Viork Todar (Hew York: MoGraw-H111 Book Company, Ino., 1956), p. 239

2. A. Humphreys A. R. Traxier, Guldanoe Services (Onloagoisclence Research Associates, Inc. T. 1954), pp. 189-90 
centered, involves the students choosing a panel from their own group to handle the discussions. 
CHAPTER III

\section{METHODOLOGY}

Subjects for th1s study were 194 elghth grade students from seven out of eleven group guldance classes scheduled for the funtor hlgh school. Of the seven elasses, three (sectione 5,6 and 11) were celected to serve as control groups, and four (aections 3, 4, 7 and 9) were designated as experimental. Structured disussions were promoted with the four experimental soctions, whereas none was conduoted with the control.

Student-centered discussions were permitted in two of the four experimental sections. That 18, members of the group selected a panel to lead the disersion and formulate the viows and concluaions of the members. In the other two oxperimental sections, the counselor led and moderated the discussion and oumbarized the opinions and judgment of the group.

The material used in the discussions congisted of two questionnalres comprising twenty-five questions, equirelent in content and repponse a far as it was posaibie. The questions referred to problems comon to youth at an elghth grade level of social experience. Care was exerciaed to implify the wording of the questions, Inamuah as the aggregate of the geven group guldange olasses represented a apread 
of Intelilgenoe quotiente from superior to borderline. An attespt was made to word the questions so as to reduce to a minlmus posaible mistaterpretation. The questionnaires were labeled list A and Iist B, and each provided a cholee of three anawere for each quention: "Yes," "Don't Know," and "Ho." The regpondent merely placed a check mark in the oolumn of his choice.

List A was given in the opring of 2958 to seren group guldance clesses. After four alscusalon perlods List B was given. The studentg were instructed to read each quegtion carefully and then place oheok mark under the heading of the angwer of their cholce. Fach question was to be answered before returning the questionnalre to the counselor. To minisize any influence the counselor may have had on the re- 4 spondent's cholee of answers, the groups were told not to write their namea on the questionnalrea.

In the four experimental groups, four consecutive group discuesion pertods were neoded to review their inftial oholce of anawera prior to reteating with Ilst B. Bach member of the experimental group was allowed to use an extra unmarked copy of Ilst $A$ as a guide during the discussions.

In the school where the study was made, the entire eighth grade 18 asembled into eleven homogeneous ability groups. Pup1l are grouped homogenoouly acoording to individual seorae made on group intelligence testo. As mentioned previousiy, this study was conducted with ceron of these groups. Section three and seven from the expert- 
mental group were seleoted for conducting student-oentered forums, and sections four and nine from the experimental group were held as counselor-motivated forums. Sections three and seven and four and nine were metched with respect to Intelligence, as meagured by an Ot1s Quick Scoring Mental Ability leat form BM. Sections five, six and eleven served as control groups

After testing, an item analysis was made of the choice of answers from each of the soven groups. The ghift of opinion on each 1tem from postive to negative, or vioo versa, indicated by the examination of the answers made by the experimental groups, was compared with any apparent consistency of responses to the same questions from the control groups. Special note was made as to which technique, counselor-centered or student-centered forms of discussion, showed the greater shift in opinton.

From Ist $A$ and Ilst $B$ ten corresponding questions were selected on which the experinental groups regigtered a shift of oplnion. These questions were then analyzed in an attampt to discern possible or probable causes for these ohifts. Iater, 1t was declded to use these ten oorresponding questions as a basio for follow-up.

Retests were conducted with two of the four disoussion groups in the fall, after a time lapse of five months, or when the students were in the ninth grade. It was decided to reverse the order of items for the retests. Ten questions from Ilst B were administered and followed by dicusalon. After one disoussion period the two groups were teated a 
week later with ten equivalent questions from List $A$. Whe overall shift of opinion evidenced by the choice of answers was again converted into percentages. These data were uoed a a basis for conelualons concerning the fficacy of each of the types of discursion in promoting attitudinal ohanges in social behavior. By reversing the order of retest, that is, in adminiatering List $B$ before Liat $A$, it was expected that a higher correlation of the effects of group discusion would be evident. Th1s reversal was designed to equalize the effect of carry-over in choice of answer should one question have more emotional appeal than its correaponding equivalent. Emplrically, by reverbing the teating order, one oblique response would have a tendency to cancel out the other when comparing the anawerg to those given for the 1dentical question earlier in the year.

A combined listing of the twenty-five questions from List $A$ and Iist $B$ are found in the appendix ${ }^{I}$ of this study. An asterlsk marks the sets of ten questions selected for the retest. 


\section{CHAPRER IV}

\section{PRESEMTATION OF DAPA}

The results are based upon the responges of control and experimental groups to problems of soclel behavior that wer presented to them. A method was devised for eveluating the response of pupilo to the twenty-five questions on the equivalent questionnalres, An angwer which was deemed logioal, according to generally acoepted standards, was selected for each question on ilst $A$ and Iist $B$ as the "Right." The resulta of the tabulation are show in Tables 1 and 2 . The percentages of the "Right, "Don't Know," and "Vrong" responses made by all seven group guldance classes are Indicated. Included in the tables are precentage figures of preand poat diacusalon tabulation for the purpose of fac1li-: tating observation of differences in the effleacy of forum motivation counselor-centered and atudent-centered diseusaion.

Student-centered seotions 3 and 7 have the greater percentage of atudents choosing right answerc on Ilst B. Without exception, all seven groups show shifts of opinion during the period between the administration of II $A$ and Iist B. The respondents of the experimental groups reveal an appreciable shift from positire to uncertaln. The exception appears among members of seotion 7 where the shift 
is to the wrong answer. Six of the seven group guldance sections show almost a ten percent shift from the "Right" column to the "Wrong" colum between List $A$ and Ligt $B$. The only exception is section 3 which ahows an inorease of five pereent.

A more definitive comparison of the merits of student and counselor-centered group discussions was attempted by making an item tabulation of the shift in responses between Iist $A$ and ligt B. A notation was made of the "Wrong" and "Don't Know" responses that an experimental gection made. The difference in total responses was established by subtracting the total of the uncertain responses on one list from that of the wrong on the equivalent list. For example, on Iiat A certain question had fifteen correct responses, f1ve "Don"t know," and one "Wrong." After disousgion the students responded to the same question on equivalent liat $B$ with ten "Right," nine "Don't know," and two "Wrong." Adding the "Don't Know" and "rong" regponses for thet question on both llats and gubtracting one from the other shows a difference of five. When twenty-one students angwered the question there was an apparent shift of opinion of 23.8 percent.

Tables 3 and 4 show the total shift of oplnion of all seven group guidance classes. Adjutments were made in computing percentages for all groups to compensate for absenos of pupils on the different days Iist $A$ and List $B$ were given. With the exception of eotion 5, in which there wa no change, attendance varled at all section meetings by only one or two pupils. 


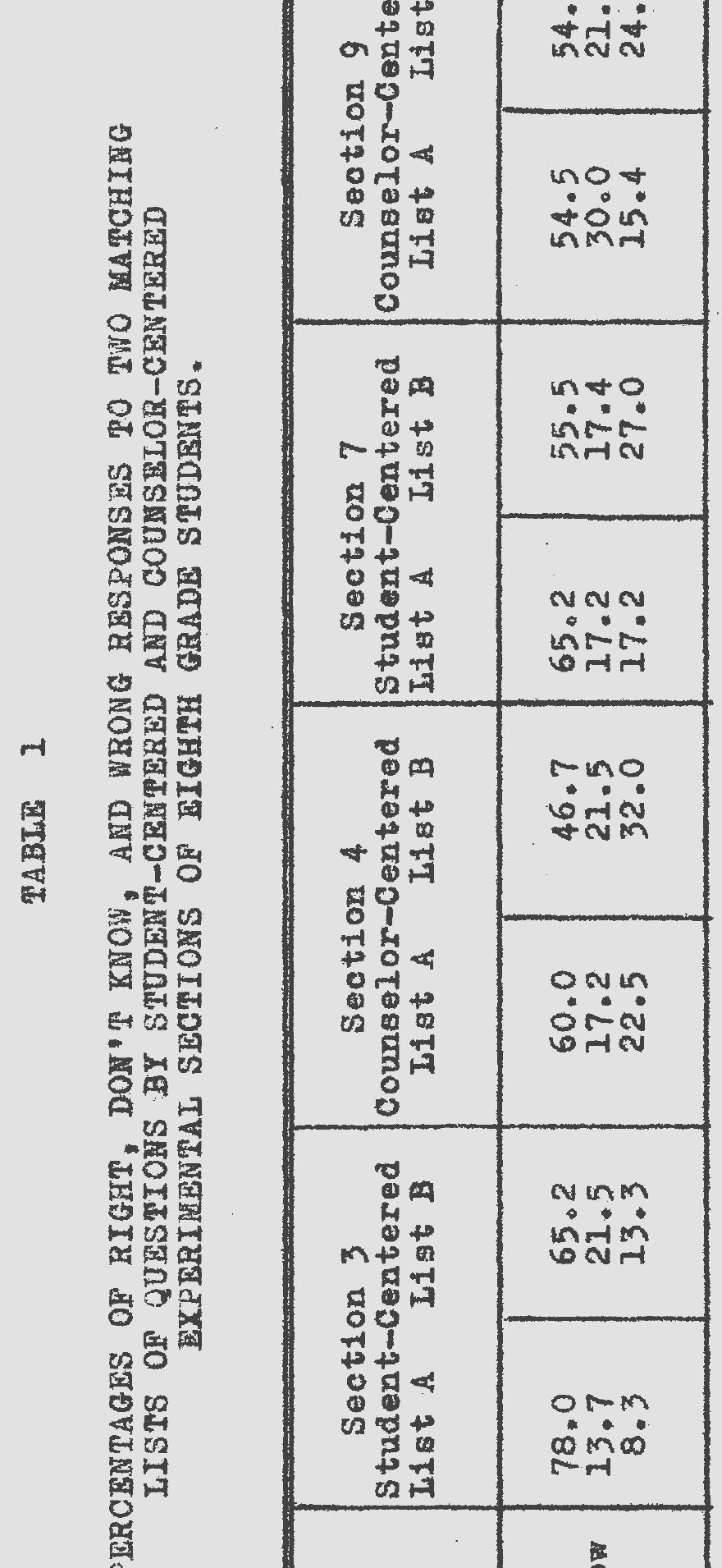




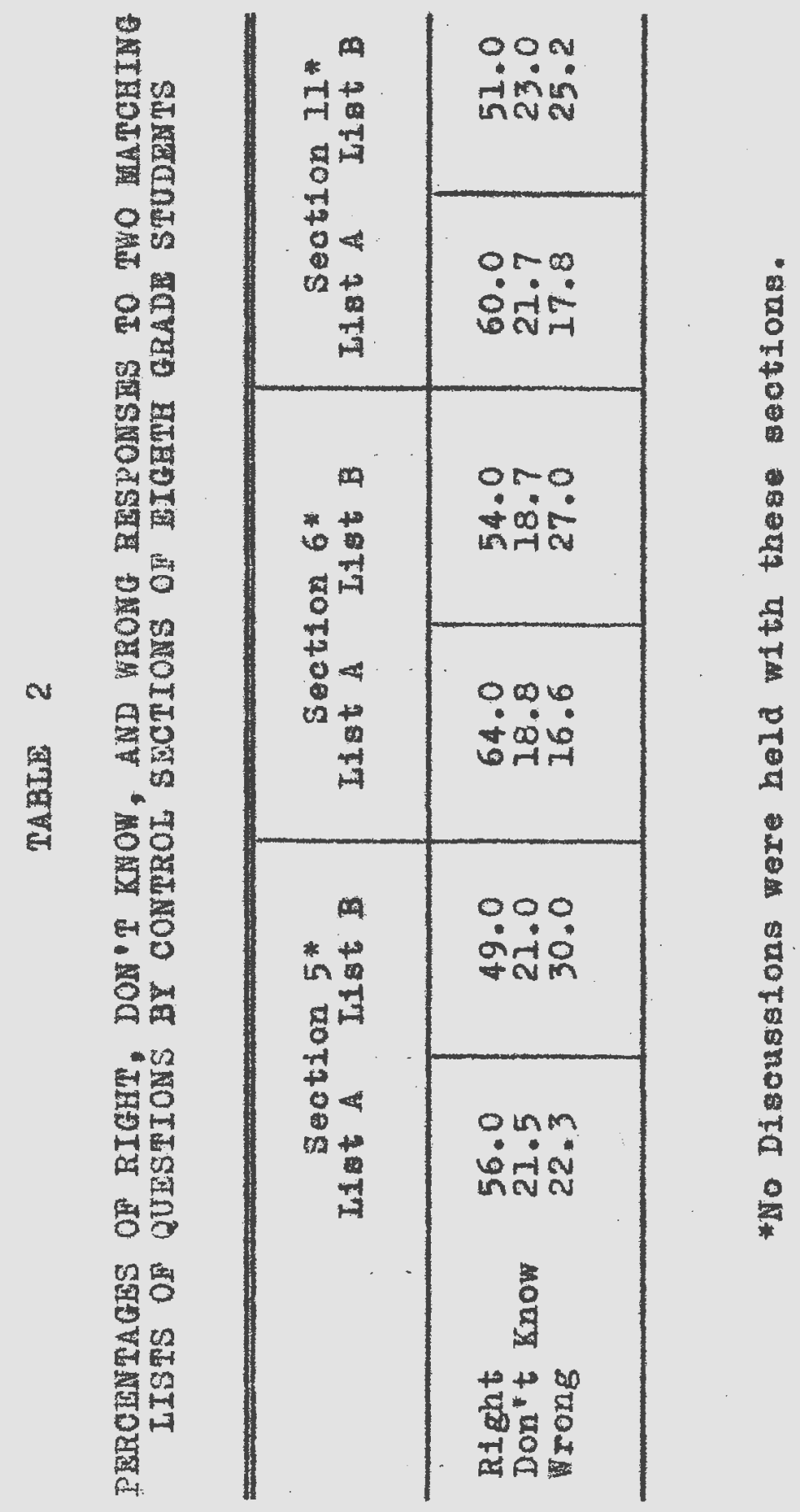




\section{TABLE 3}

COMPARISON ON PERCERTAGE CHANGE IN RESPONSES AMOIG EXPERIMENTAL SECTIONS BETWEEN ADMINISTRATION OF

IIST A AHD IIST B

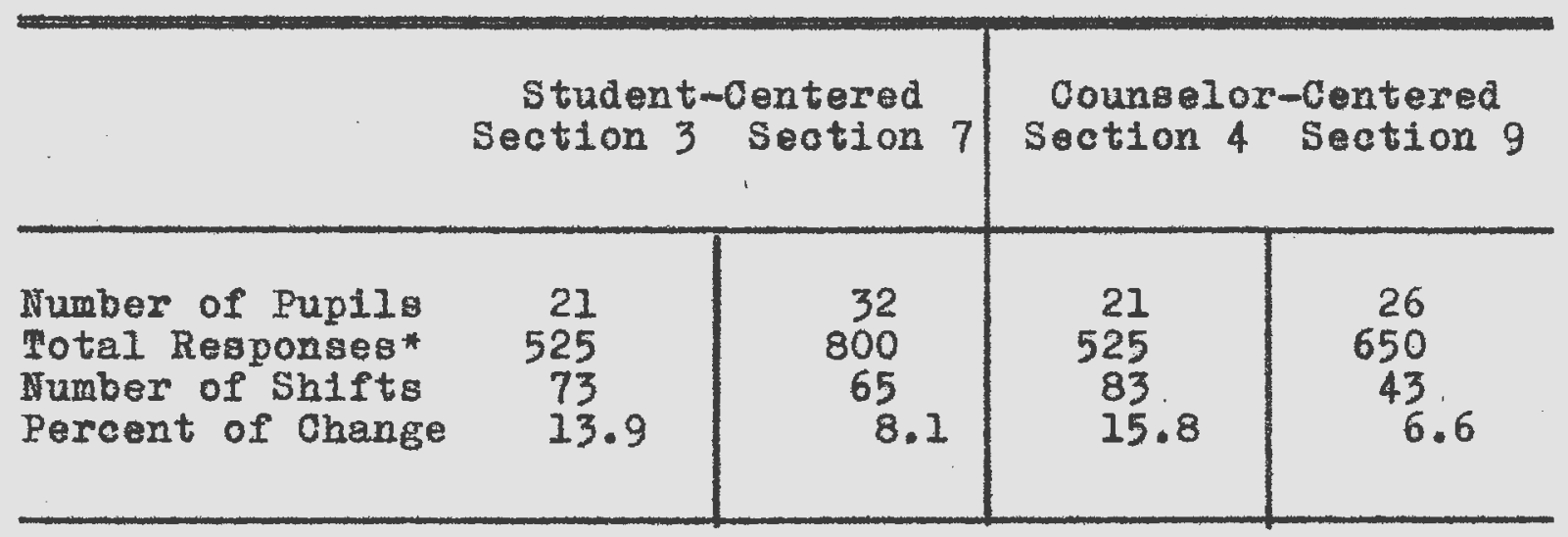

TABLE 4

COMPARISON OF PERCENTAGE CHANGE IN RESPONSES AMOHG CONTROE SECTIONS BETWEEN ADMINISTRATION OF

IIST A AND IIST B

\begin{tabular}{lc|c|c}
\hline & Section 5 & Section 6 & Section 11 \\
\hline Number of Pup1ls & 28 & 31 & 20 \\
Total Responses* & 700 & 775 & 500 \\
Number of Shifts & 65 & 104 & 35 \\
Percent of Change & 9.3 & 13.4 & 7.0 \\
\hline
\end{tabular}

* Responses are the produot of the number of pup1ls multiplied by the number of questions (25). 
When oomparing the experimental sections with control sections the peroentage of shift in opinion appears to be negligible. For example, control section 6 presents a shifting of oplnion of 13.4 percent againgt 13.9 percent in experimental section 3 . Upon referring to Tables 1 and 2 , it is observed that the shift of opinion in section 6 is from "Right" to "irong;" whereas the mijor shift of opinion of experimental section 3 is toward the unsertain category. The same apparent conclusion can be inferred from experimental sections 4 and 9 and control sections 5 and 11. When the control and the experimental sections are contrasted, it would seem that discussions conducted with the experimental sections have little effect in changing the behavioral conoepts of elghth grade pup1ls.

Table 5 reveals a contrast in change of opinion in percent between the student-centered and counselor-centered types of group discusgion. In addition, the average in peroent for these experimental section is compared with the average of the three control sections. The pereentages were obtained by adding the total shifts of oplnion for each group guidance class and dividing by the total number of responses for each section. The control groups indicate a shift of opinfon of 10.3 percent againgt a 10.6 percent in the experimental clasies. A differenoe of only.3 of one percent is evident. Likewise, the same difference in percent exists between counselor-centered and studentcentered forums. With this experiment each appear about equal in motivating over-all chenges in attitudes. 
AVERAGE PERCBNTAGES OF CHANGE FOR COMBIMBD EXPERIHEWTAL AND CONTROL SECTIONS

Sectiong

Percent

Student-Centered........ 10.4

Counselor-dentered. . . . 10.7

All Experimental. . . . . 10.6

All Control......... 10.3

For interpreting these percentages it is important to refer again to Tables 1 and 2. The slight avantage of the experimental over the oontrol sections, in terms of opinion ohift, is supported in the instances of sections 3 and 4. In these two groups there 1 a a tendenoy to awing toward the "Don't Know." At Ieast, in the te two groups, discussion may have had the effect of enoouraging the students to be more reflective about behaviorel problom. Table 6 shows the mental ablitty gores of all seven group guldane sections along with number, quartile, and range of each section. The basic intelligence of each section is but one of soveral factors which might be related to the results of group discussion. The range of intelligence scores of the combined experimental section is 71 to 120 in contrast to 74 to 113 for the soctions serving as control. The mathenatical middle for the range spread of all the experimental sections 18 95.5, while that of the control sections 1s 93.5. The arerage median seore of the experimental vections $1 \mathrm{~s} 99.9$ in contrast to an arerage of 96.8 for those designated control. 
TABLE 6

COMPARISON OR MENTAL ABIJITY SOORBS OP ALI SEVEA GROUP GUIDAMCE SECTIONS

\begin{tabular}{|c|c|c|c|c|c|}
\hline Sect1on & Iumber & Quart110 & Quart118 2 & $\operatorname{Quart}_{3} \mathrm{O}_{3}$ & Rango \\
\hline $\begin{array}{l}3 \\
4 \\
7 \\
9\end{array}$ & $\begin{array}{l}24 \\
24 \\
32 \\
26\end{array}$ & $\begin{array}{c}p x 1 \text { ] } \\
104.0 \\
100.0 \\
90.5 \\
82.6\end{array}$ & $\begin{array}{r}n+a 1 \\
1.10 .6 \\
105.0 \\
96.0 \\
88.0\end{array}$ & $\begin{array}{r}113.2 \\
111.0 \\
102.6 \\
94.3\end{array}$ & $\begin{array}{l}98-120 \\
94-117 \\
80-104 \\
71-100\end{array}$ \\
\hline $\begin{array}{r}5 \\
6 \\
11\end{array}$ & $\begin{array}{l}31 \\
34 \\
20\end{array}$ & $\begin{array}{c}c \mathbf{n} t= \\
99.0 \\
94.0 \\
94.0\end{array}$ & $\begin{array}{l}01 \\
102.0 \\
101.0 \\
87.3\end{array}$ & $\begin{array}{r}105.0 \\
103.0 \\
93.0\end{array}$ & $\begin{array}{l}83-113 \\
74-112 \\
77-99\end{array}$ \\
\hline
\end{tabular}

As mentioned previously, ten questions each were selected fron matching Lists $A$ and B. It was deelded to adminlster these two matching 11 sto the following bohool year, when the students wauld be in the ninth grade. Sections 3 and 9, on the basis of extremes of average intelligenee, were chosen for this study. The regults are shown on Tables 7 and 8 . Table 7 gives a breakdown by percents of the "Right," "Don't Know," and "wrong" responser for the ten selected follow-up questlons. It ahould be noted that the percent shifting from "Right" to "Wrong" is not so high as when the puplls were in the elghth grade.

Two factors should be considered as contributing to the loss in percentage of wrong anawers. One is the reversal of the order in whioh the lista were presented. 


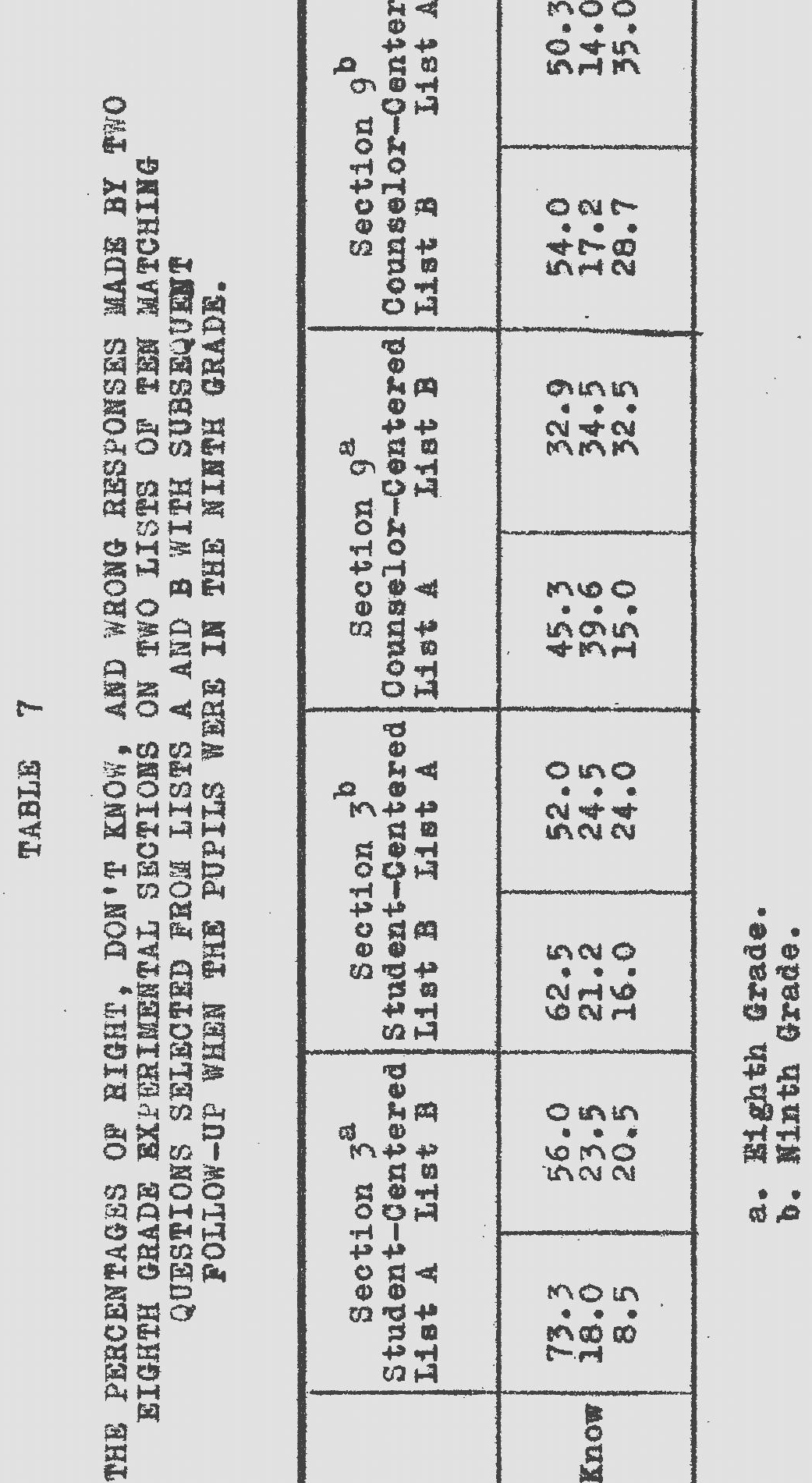


SARTE

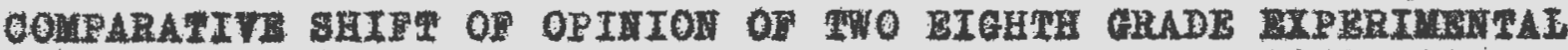

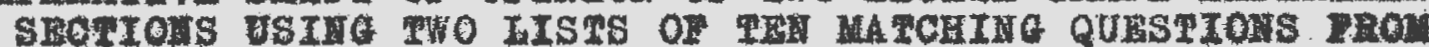

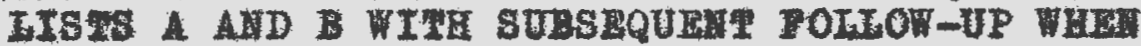

PUPIIS WIRE III THE MIHTH GRADB.

a

\begin{tabular}{|c|c|c|c|c|}
\hline & \multicolumn{2}{|c|}{$\begin{array}{l}\text { Student-centered } \\
\text { Groap } 3^{\mathrm{a}} \text { eroup } 3\end{array}$} & \multicolumn{2}{|c|}{ 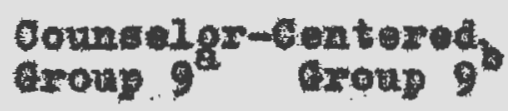 } \\
\hline 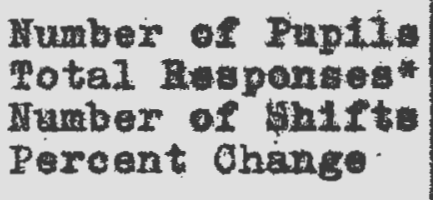 & $\begin{array}{r}21 \\
210 \\
34 \\
+\quad 16.0\end{array}$ & $\begin{array}{r}23 \\
230 \\
22 \\
9.6\end{array}$ & $\begin{array}{r}26 \\
260 \\
21 \\
8.2\end{array}$ & $\begin{array}{r}26 \\
260 \\
25 \\
9.6\end{array}$ \\
\hline
\end{tabular}

a. B1ehth grade

B. Hinth Grede

- Hamber of pipile antiplice by number of auestions (10). 
In the follow-up, Int B preceded Ilst A. Another fector is the maturation of the pup1ls.

In the eighth grade, youngaters generally are in a period of adolescent development when some of the major phyaieal changes take place. The interim of five months between the initial testing and the followmp should be considered.

It is shown in Table 8 that section 3 had a greater shift in opinion ( 16 percent) when the two tests were initially given. The follow-up ohow that seotion 3 had a drop in percentage of 6.4, whereas, section 9 had an incrouse of 1.5 percent. It 1 s observed that section 3 and seation 9 have identical percentages ( 9.6 percent) in shift of opintion on the follow-up test.

Throughout this study no attempt was made to identify the respondents. In keeping all responses anonymous, it was assumed that the puplis' cholce of answers would reflect their convlotions with little attempt to please the counselor. 


\section{CHAPTER V}

\section{CONOLUSIONS AUD RECOMOGEADATIONS}

This study has invertigated some of the attitudes beliefs, and concepts of eighth graders related to problems Involving deotsions of personal and soctal behavior. This Invertigation has attenpted to reveal some of the values which might be attributed to group disoussion a mediun for the modifioation of soclel values and attitudes. From the data presented in the previous chapter number of concluaions may be properly drawn.

1. The apparent influence of group a1scussion, as measured by responses of students to two sets of comparable questions on sooial attitudes, does not follow a congistent pattern with students having the discussion experience.

The data of this study revealed that experimental sections 3 and 4 moved glightly frow "RIght" to "Trong" in their responses, but also increased in the percentage of responses on "Don't Know" on list B. Experimental section 7 ahifted also from "Right" to "Wrong" but remained constant in the "Don't Know" column. Experimental section 9 remained constant in the "IIIgt" colven, increased in the "Wrong," and deoreased in the "Don't Know" columns. In contrast, the the three control sections shifted quite consiatently from 
"Right" to "Wrong" and remalned constant in the percentage of "Don"t know" responses.

This conclusion is further substantiated by comparison of the percentage change of attitudes among four experimental sections. The percentages of change rary widely from 6.6 to 15.8 percent. The control seotions show slightly more consistency with a range from 7.0 to 13.4 percent of ohange in responses from List A to list B. It might be concluded that group discussion was reoeived and asaimilated in widely varying ways by the four experinental sections.

2. Group discusion appears to have the effect of meking the relatively more intelifgent students more reflective in making cholcas regarding problems of social attitudes.

When experimental sections 3 and 4 were compared with seotions 7 and 9 it was shown that the former two gections had an Inereage of "Don't Know" reaponses on Iist B. In contrast, ection 7 showed no increase in the "Don't Know" reaponse and seotion 9. howed deorease. A logical inference from these limited data 1 that sectione 3 and 4 , with relatively high IQB became more reflective about the questiong as a result of group liscussion and were nore cautlous in their responses. This is further substantiated by the fact that both sections 3 and 4 showed a much higher percentage of shift than sections 7 and 9. In other words, they may have been thinking more about the queatione and 
the group as a whole made more 1 ter ohifts among the threo possible reapones.

3. With regard to the influence of leadership followed in group aiscussion, there is no appreoiable difference between the atudent-oentered and counselor-centered leadership.

One would have expected a student-centered disousaion with aotive involvement of a majority of atudents to have had greater influence upon values important in the peer culture, than the counselor-centered discussion. The data of this study revealed little difference between the two types. The counselor-centered actually had a sightly larger average percentage of change of attitude. The results on this point are quite inconelusive, since the procise differences between the counselor-centered and tudentcentered patterns were actually not as pronounced as they might have been with a more autocratic, highly directive, counselor.

4. The differences in change of attitude botween the experimental section subjected to discusaion and the control sections who held no discusgion wero negligible as measured by the two test instruments.

It might have been antiolpated that the discussion groups would move from a lower to higher percentage of "Right" upon the adinistration of Ilat B. Actually, all four experimental sections soored a lower percentage of "Right" answers on this second list then they did on the f1rst one. This trend was also indicated in the same 
relative proportion for all three of the control seotions. One may infer that list $B$ choices were more thought proroking than those in Iist A. Even if this were the case, the experimental sections did no better on List $B$ than the control sections, even with the benefit of four organized discugsion periods. It may have been true that the control geotions discussed these 1ters informally outside of olass, perhaps not to any great extent since they did not have the questions in their possession outaide the olass room.

A further ohock on the comparability of Ilat A with Ilat 8 was made by a follow-up with oxperimental sections 3 and 9, approximately five months later, when the students ware in the ninth grade. Ten selected items from Iist $B$ were given first, followed two days later by ten comparable itema from Ilst $A$. These itema were also discussed, but the same pattem of decrease of "RIght" responses for both sectlons prevailed. These results would further subatantiate the conolusion that group discussion per se does not exert a measureable influence upon attitudes in the direction of conforming to the more established social mores.

5. The extent of group interaction during group dissusaion may be a factor in stinulating a nore refleotive response among group members.

Ievel of intelligence has already been indicated as a possible factor in a more deliberative and cautious reaction to problems involving social attitudes. An additional factor, closely related to the brightness of students, Is the extent to which they interaot in the sharing of 1 deas. 
It was observed by the writer that both sections 3 and 4 engaged in discussion with comparable enthualasm, even though one was tudent-centered and the other counelorcentered. Both showed a relatively high percentage of change in responses between edministration of IIst $A$ and Iist $B$ in contrast to sections 7 and 9.

When the degree of interaction in gection 7 was subjectively compared wh that of section 9 it was observed that otudents in seotion 7 chowed muoh nore enthusiasm for intergeting with each other in the discussion of Items on list A. The date revealed that neotion 7 renained congtant in the "Don't Know" column while section 9 deoreased appreoiably in the seleotion of "Don"t know" and inereased correspondingly in the "Wrong" column. Thio might be inferred as an indication of somewhat unreflective responses among members of section 9 . who did not interect dynamioally with their peers. The median IQ of section 7 18 eight pointe higher than section 9. It may be expected that pupils with higher intelligence are better equipped to verbalize their thoughts and problems, and therefore interact more meaningfully and with greater facility.

It is recommended for a future study of this kind that the following be considered:

1. Bach question should be carefully matohed as to content validity and reliablitty. For example, questions from List A and corresponding counterparts from Iist $B$ will illustrate. 
44. You are with a Iriend in a atore and you se him piok up an artiole from the floor and put it in hia pocket. It was something that had fallen from the counter. Your frlend explained he had not taken anything. The artiole was on the floor and ilfty. Pexhapa, it would have been otepped upon and broken. vould you overlook this act of your friend?

45. Your friend ploke up a pen in the hall. You oe hil quickiy put it into his pooket with no explanation to you. You both know to whom the pen belonge. Would you orerlook this act of your Ixiond?

The basio concept of these questions is finders Keepere." After dscussion, there was a change of oplnion away from the correct anawer "No." The first question inrolved an article that fell from the counter; whereas the Item in question $4 \mathrm{~B}$ wa a lost pen. The group feeling about a logt pen should be conaldered in analyaing the response to this question. Some atudents would not cenare a friend for pleking up a useful artiole like a pen in the hall, yet, the same pup 11 g may be critical of the same friend for find- ing an unamed article that has fallen off a counter is a store.

54. You purchase something at a store and the olerk gives you $25 \%$ too much in change. The store is busy and they appear to be dolng b16 businese. It can be aseuned they wiII. never mise the 25\%. Would you go back and call the mistake to the olerk's attention?

5B. You purohase some ailk at the cafeteria. you are given four cents ingtead of three centa in change. Is it necessary to go to the trouble of returning one cent?

The accepted answer for queation fIve 18 "Yee." A noticeable shift from "Right" to "wrong was observed when the equivalent question on Iist $B$ wes scored. In "An 
31

question, twenty-five cents has been orerpald. In dontrast, only one cent is involved in question "B." The atfference between the two anounte could be inotrumental as a cause for the shifting of opinion fron "R1ght" to "Wrong." "Terhaps, a aterial rather than a moral value colored the deoision causing ahift to the "Wrong" answer for the question. It was the thought of most of the reapondents that one cent was not worth returning.

2. Horms ohould be extablighed for the two sets of questions. This could be accomplished by a pilot administering of the questions, without aiscussion, to seventy or olghty eighth grade students other than those selected for the experiment.

3. The questionnalres should be coded so the answers of each respondent oould be 1dentified. A check list of Individual responses could be prepared and individuel alferenoes in opinion shift could be noted and craluated.

4. Since this study sampled attitudes and opinions about problem of social behavior many of which were conditioned in early cinllahood, It is understendable that it takes more than few brief alscugsion periods to effect any changes in conceptr. It would be advisable to lengthen the discussion period and reduoe the number of questions.

5. A soologram should be prepared to ldentify the "star pupil or pupila" for student-oentered diseusalon sections. The selection of etudents to whom the majer portion of the room is attracted might oerve to marpen the 
interest of the participants. Host attitudes exhibited by chlldxen are those that have been fixed by atrong emotional involvement through interaation with others. Iarighurat and Taba make this observation:

...It need hardiy be sald that the development of character, as is true of any soofalizing process, take place in an emotional context and in relation to other personalities. The byplay of feelings and emotion has profound influence on the noture of moral belief and thelr fficacy in influencing conduct. 1

The selection of a "Btar of the group" to lead the discussiona night oreate more enotional influence, thus affecting deepseated fixation that could result in changes in opinton.

6. Role playing ghould be used for motivating and enlivening the dsaussion periods.

An opportunity would be thus afforded for gaining emotionally colored impressiong through seelng the problem acted out and partielpation in the acting procers.

7. Seleoted human relation novies or alides should be ut1lized during discusstons to portray soenes that are not easlly desoribod in words.

Impreseions may be made by vieual ald that would be dificult to produce th group disougsions alone. Though nothing actualiy positive in favor of group gutdance has been revealed in thia otudy, 1t should not bo construed as an indictment against 1t. The investigation attempted to determine if group disoursion could change any

$I_{\text {Robert J. Havighuret and H1lda Taba, Adolegcent }}$ Chareeter and Eersonelity (How Yorki John 1ley Sons, Ino., 1949). 0.95 
exlgting concept eighth grade boys and girle have on social behavior.

By and large, many of the problems in List $A$ and list B, stimulated patterns of thinking that had been developed prior to attendance at the funtor high school. Group discusaion was attempting to nodify some exroneous conoepts that may have been made rigld through habit. If the problems had required only superficial decisione and opinions were unformed, the resulte of the brief disoussions may have been more gratifying. Along this vein, Utterback has this to say about conferences:

... Those who entered the conference with opiniona stili unformed shifted most; those whose views were pronounced but yet not held with complete confidence ranked second in amounting of shifting; those who beld opinions with oomplete confidence inffted least. I

Due to the relatively small amount of time the ohild spends in sehool, Jones 2 points out it is probably impossible to achleve, through instruction, any worthwhlle inprovement in what he term oharaoter and citizenship. The good that may bo don 18 grossly influenoed by such factors as home background, mental ablitty, culture, and subeulture.

It appears group disoussiong could oreate more changes In attitudes and concepts if those attitudes and concept. have not become fixed through uae or action. If group discusion is Indioted, it is because a sudden change in the

Ifillan E. Otterback, "The Influence of Oonference on Opinion," The Quarterly Journal of speech, XXXVI (October, 1950). 365-70

${ }^{2}$ Vernon Jones, Character and Citizenghip Training in the Public Sohool (Chicago: The Univeralty of Chicago Press, 1936), p. 312 
34

concepts of the participants is expected imediately after a discuasion period rather than a slight change made in progreasive steps through a sertes of organized group discussions. 


\section{ACKUOWLEDGEMEITS}

It is a pleasant task for the writer to aolnowledge the graelou cooperation of Dr. Frank M. Pelton and Dr. E. Kenneth Carpenter in the writing of this thesis. Their considered suggestions during the "drafting" was indeed helpful.

Special thanks are due Dr. S. Mlarvin Rlfe for hts encouragement and assistance during the "hoe and spade" period In the development of this study. His guldance in the handing of data made it all possible.

J.R. 


\section{APPENDIX}

QUESTIONS OP EQUIVALUNT IISTS A AND B COMBINED THOSE HARKED * WERE USED IN THE FOLLOW-UP.

1A. If you belonged to a aramatie olub and you did not get the part in a play that you folt you could do better than the one chosen. vould you quit the club?

1B. If you belonged to a camping club whioh never camped at opots of your cholce, would you quit the olub?

2A. It is storay night. The streets and roadg are covered with $1 \mathrm{ce}$ and $1 \mathrm{t}$ is angerous. There 18 a basketball game to be played ten miles away. You have doclded not to attend but remein at home and finioh a gooial studies assignment. A close friend drops by and asks you to go. Would you refuse?

2B. If you have made up your mind to stay home and work on a chool assignment and a 010 se friend drops by and asks you to go out with him. Would you refuse?

3A. You are with a gang and thay deolde to break gtreet 11ghts. You throw rooks with the regt of the ganf but you are careful to aim 50 as to $1 \mathrm{ss}$ the 11ghts. Are you doing anything wrong?

3B. Boy you are with decide to destroy some property in the nelghborhood. You pretend you are breaking and destroying thinge but you do no damage. Are you doing anything wrong?

*4A. You are 1 th a friend in a tore and you see him pick up an article from the floor and put it in his pocket. It was oomething that had fallen from the counter. Your friend explained he had not taken anything. The article was on the floor and dirty. Perhaps, it would have been tepped upon and broken. Would you overlook this aot of your friend? 
*4B. Your friend ploks up a pen in the hall. You see him quickly put it into his pooket with no explanation to you. You both know to whom the pen belongs. Would you overlook this act of your friend?

*5A. You purchase something at a tore and the clerk gives you 25 too much in change. The store is busy and they appear to be doing a big business. It can be assumed they will never mise the 25\%. Would you go back and call the mistake to the clerk"s attention?

*5B. You purchage some milk at the cafeteria. You are given four cent instead of three cents in change. Is it necessary to go to the trouble of returning one cent?

6A. You do not like to carry your lunch, so jour mother gives you 30 s a day so you buy warm food at the cafeteria. You spend most of it for soft drinks and candy. Your mother does not ask how you spend the money. Is it all right for you to continue to do this?

6B. You are given ome money for a church offering each Sunday. You have developed the habit of keeping a small portion of it to spend on candy and soft drinks; the rest you give to the church. If no one has told you to give all of the money to the ehurch $1 \mathrm{~s}$ it all right to continue dolng this each Sunday?

7A. You run around with a crowd of boys all of whom you like very much. Two of the boys occasionally teal small inexpensive items from a corner drug store. Would these acts make eny aifference in your preference for being part of the group?

7B. Two boye in a olub you belong to occasionally take small amounts of money from thelr mothers' pooketbooks to buy candy, some of which they give to you. would this make any difference in your belonging to the club?

*8A. You Iike Betty but you know that Betty's habits, in some instances, are not good. For example, she slips out of her house at night and meets ome friends at a certain corner. These frienda are of queationable charaoter. Would you continue the friendship? 
*81. You have a friend you like very much but he fools his parents and slips out at night to run around with a gang. This gang is often in trouble with the polfoe and neighborhood. Would you continue the friendship?

9A. A boy in your erowd, who it 16, gets permission to use his father's ear with the understanding be is to drive carefully. You know about this but you also know he drives reaklesgly. Since it is not your father's car would you be concerned bout it?

10A. You have a friend who continually use foul and obseene language and repeats dirty stories. Would you oontinue the friendship?

10B. A good friend of yours continually makes foul remarks about peoplo and tells dirty stories. Would you continue the friendship oven though he is popular with some boys and girls?

11A. Small articles around the school and in the gym. are being stolen. You know the thief. Wothing of yours has been atolen but the principal is anxious to oatch the one reaponsible. Do you have an obligation to ldentify the thief?

11B. You know a person who steals and is not to be trusted. Something is taken from a olagaroom he attends. Do you have an obligation to identify him?

12A. A friend of yours bunks school. You can write him an excuse that will get by and save him from being suspended. Would you write this excuse?

12B. Is it all right for you to write an excuse for a friend if it will keep him from belng suspended?

*13A. You are a good otudent in school liked by the teachers and classmates. Your name is among the Ilst of those who are to be elected by the sohool as the "best citizen." At home you are surly, diarespeotful, and neglect household chores, would you allow your name to remain on the candidates list? 
*13B. Tou have a good reputation at school and Jour name is ameng those to be chosen "allaround eitigen." At hore you aro surly, selfish, disrespectful, and Just an "aliaround heel." Since there 15 ilttie resemblance between your conduct at sehool and at home is it right to lot your name remain on the ballot?

14A. You are not 16 but a friend who is comes by in hie father's car that he has been allowed to have of the afternoon. You go for a drive and he asks you to take the wheel. You have learned to drive your unole's car around a farm. You have nover driven on the highway. You are anxious to drive your friend's car. Would you drive it for a mile or two?

14B. You are not 16 but you know how to arive a car. A friend who is 16 gives you permission to drive his car for a fer miles down the highway. Would you accept the invitation?

15A. A mistake is made in your favor by the teacher in grading midterm exams. If you report the ristake it will ohange your grade from a "C" to a "D." Fould you oall the mistake to the teacher's attention?

158. A mistake is made by the school offioe in cheoking marks and your name is placed on the honor roll. Are you doing anything wrong in neglecting to call the exror to the attention of the offloe, if to do so, would keep you from getting the bicyole promised by jour father?

* I6A. You find a pocket alctionary and you do not make an honest effort to find the owner. You use the dictionary and it helps you with your achool work. Are you doing anything wrong?

* 16B. You find a ball polnt pen the kind you have always wanted, and it is a great help with your school work. Are you doing anything wrong in not trying to find the owner?

17A. You hear gossip about a friend which you know is untrue. It 1s so funny that it makes you the center of attention when you repeat it. Would you continue telling the story when your friend is not around? 
17B. In 1t all right to oay unkind thing behind a person's back. Just in fun?

18A. A good Iriend of yours 18 trying to oopJ from your paper during a test. Would you cover your paper?

18B. Your friena keeps looking at your paper during the midyear exam. Would you oover your paper?

19A. Your teacher is giving a midyear exam. Your friend has the aubject ilrat period and you have the class third period. Wowld you ask your friend at the end of the first period what questlong were uged?

19B. Fould you ask eriend whet questions were asked on a test if you are going to have the ame teat later in the day?

*20A. You go to the movies. You oan get in for half price if you tell the tieket eeller you ere eleven. Would you do this when you have had your thirteenth birthdey?

*20B. A conductor lets you ride a train to Iew York for half fare because he think you are under age. You declde to buy Jour mother a present with the money you w111 save. Would you tell the conductor that you should pay tull fare?

21. You find a wallet at the railroad station. It contains ten dollars but there is no laentification. Would you turn it over to the lost and found?

21B. You find a wallet at the bus terminal with some money in it but there is no identification. Are you obligated to turn it into the lowt and found?

*22A. You and your Iriend are the last off the bus. Your friend ha been bawled out by the bus driver for shoving. To get eren with the bus driver he euts some seats indfe. It 111 be hard to find out who did the damage as the bus carries both $\mathrm{high}$ and junlor high sohool students. Would you insigt that he tell the guidance counsolor or prinoipal what ho had done? 
*23. You soe a friend of yours deliberately damage Yes Know No school property because he is mad at a teacher. Would you insiat that your friend see the guidance counselor or principal and tell why he dia the damage?

*231. The teacher allow you to grade each other's papera ater a true and false test. Your friend whispers he did not do so we11 and asks that you change a few answers so ho will make a pasalng grade. Since it will be easy to do and the teacher w1II not cheok the marks, would you do this for your friend?

*23B. You ere permitted to grade a test paper for a friend. In order for him to make a pasaing grade you change gome of the anowers for him. If there is hardly any danger in belng caught, would you do this?

*24A. Your father has agreed to let you stay out uritil 11:30 on Friday nights. The next morning, while you are eating a late breakfast, he what time you came in. You answer, "a 11ttle after 11:30," when ectualiy $1 t$ was 1:30. Have you been untruthful?

*24B. You have been assigned to out gome mall pleces of wood at home for a club project. At the next meeting the club president ask if you have finliged with your part. You tell hin you have a few to do when you have not even atarted the work. Is this being untruthful?

*25A. During a lootball game you catch a pass and run down the side lines and make what everyone thinks, including the referee, is a touchdown. You know, while making the run, you stepped out of bounds about the five yard ine. As you return the ball to the referee you see that your footprint is juat outside the white chalk line. Would you point thig out to the official?

*25B. During a baseball game, at a close play at home plate, the umpixe oalls you safe. You know the cateher tagged you with the ball before you touohed the plate. Would you mention this to the unpire? 


\section{BIBLIOGRAPHY}

Allen, R. D., Stewart, F. J., and Schlorerb, I. J. Common Problems in Guidance. New York: Inor Publishing Company, 1938.

Bennett, M. E. Guidance in Groups. New York: McGraw-Hill Book Company, Inc., 1955.

Coleman, J. C. Abnormal Pyychology and Modern Iffe. Chicago: Scott, Foresman and Company, Inc., 1955.

Havighurst, R. J., and Heugarten, B. I. Society and Education. Boston: Allyn and Bacon, Inc., 1957.

Havighurst, R. J. and Taba, H. Adolescent Character and Personality. New York: John Wiley and Sons, Inc.. 1949.

Helsler, W., Smedley, M., and Campbell, C. M. "Group Dynamios: A Junior High Class Experiment," The Clearing House, XXIV, (November, 1949), 151-54.

Henry, N. B. The Integration of Educational Experience. (The Fifty-Serenth Yearbook of the National Society for the Study of Education, Part III), ChIcago: The University of Chicago Press, 1958.

Hollingshead, A. B. Elmtown's Youth. New York: John Wiley and Sons, Inc., 1949.

Humphreys, J. A., and Traxler, A. E. Guidance Services. Chicago: Science Research Associates, Inc., 1954.

Jersild, A. T. The Psychology of Adolescence. New York: Hacmillan Company, 1957.

Jones, V. Character and Citizenship Praining in the Public Schcol. Chicago: The University of Chicago Press, 1936.

Kuhlen, R. G. The Psychology of Adolescent Development. New York: Harper and Brothers, 1952.

Moustakas, C. "A Human Relations Seminar at the MerrillPalmer School," The Personnel and Grudance Journal, XXXVII (January, 1959 ), 343.

Spock, B. "A Child Must Feel He Belongs." Ladies' Home Journal, IXXV No. 1 (January, 1958), 14. 
Stewart, 0. C. Att1tude Change Pollowing Coungeling \$eminare." The Personnel and Guidance Journal, XXXVII (December, 1958), 273-75.

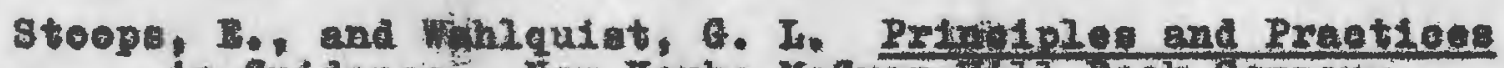
in Guldanee New York: MeGraw-illi book Company, 1958.

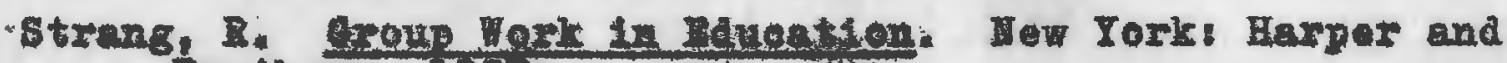

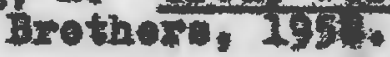

Traxler, A. It Iechniouen of Gudenee. Hew Iork: Harper and Brothers, ISy7.

- Wartere. J. High Sohool Permernel Mork Tedar. Hew Yorks Hocraw-Hin Book Company. Ine., 1956.

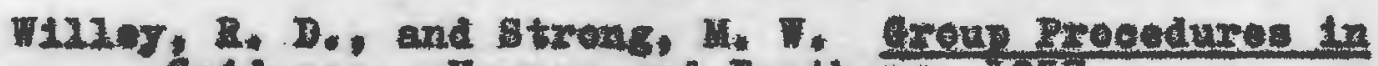
Ge1hanee. Harpor and Brothort, 1957.

Utterback, . F. "The Influence of centerenee on Oplaion." The Querterly Journel of Speech, XXXVI (Oetobox, 1950), 365-70. 